\title{
Effect of interventions with ingestion of legumes and/or supervised exercise on the lipid profile of young, healthy sedentary women*
}

\author{
Luis F. Fajardo, MD, MSc ${ }^{1}$, Dora G. Castellanos Fisiot, MgBıol ${ }^{1}$, \\ Myriam Chinchilla (QPD) Nutr, MaBiol ${ }^{1}$, Luz N. Vargas, Nutr, MgBiol ${ }^{1}$, \\ Martha Guerra, Bacteriol, MgBıol ${ }^{1}$, Leonardo Quintana, PhD², Johnson Niño, MD³
}

\section{SUMMARY}

Objective: To contribute to the knowledge of some aspects of the Healthy Life Style by studying the effects of including legumes in the diet and exercise at two intensity levels, along with the lipid profile of young sedentary women living at 2640 meters above sea level.

Materials and methods: The study included a non-randomized clinical trial with four intervention groups: exercise at $45 \%$ $\mathrm{VO}_{2}$ peak plus legumes in diet, exercise at $65 \% \mathrm{VO}_{2}$ peak plus legumes in diet, only exercise at $65 \% \mathrm{VO}_{2}$ peak, and only inclusion of legumes in diet. In each group, 20 to 23 sedentary women were included. The intervention was carried out for four weeks, three days a week. Exercise prescription was based on measurement of $\mathrm{VO}_{2}$ peak by ergospirometry; and the current intervention was monitored with heart-rate monitors. The outcome variables were total serum cholesterol, LDL cholesterol, HDL cholesterol, and triacylglycerols measured at baseline and after two and four weeks of intervention.

Results: The measurements taken of participants in the group of exercise at $65 \% \mathrm{VO}_{2}$ peak plus legumes in diet showed a reduction of $19.8 \mathrm{mg} / \mathrm{dl}$ in total cholesterol, of $21.8 \mathrm{mg} / \mathrm{dl}$ of LDL cholesterol, of $20.7 \mathrm{mg} / \mathrm{dl}$ of tracylglycerol, and an increase of $6.2 \mathrm{mg} / \mathrm{dl}$ of HDL cholesterol. The serum levels of HDL also increased in the group of only exercise at $65 \% \mathrm{VO}_{2}$ peak. $\mathrm{No}$ significant changes in serum levels were documented for participants in the group with only dietary modifications.

Conclusions: The results suggest that different interventions that meet some of the criteria for healthy eating and life style show different effects with regards to the level of change in the lipid profile components.

Keywords: Healthy eating; Lipid profile; Exercise level; Legume intake.

Efecto de las intervenciones con ingesta de leguminosas y/o ejercicio supervisado sobre el perfil lipídico de mujeres jóvenes, sanas y sedentarias

\section{RESUMEN}

Objetivo: Contribuir al conocimiento de algunos aspectos prácticos para llevar a cabo una alimentación y estilo de vida saludable, mediante el estudio de los efectos en el perfil lipídico de la inclusión de leguminosas (fríjol, lenteja y garbanzos) en la dieta de mujeres sanas pero sedentarias, acompañada de ejercicio con dos niveles de intensidad, moderada y alta, efectuados a una altura de 2,640 metros sobre el nivel del mar (msnm)

Material y métodos: Estudio de intervención clínica no aleatorizada con cuatro grupos de intervención: ejercicio a $45 \%$ $\mathrm{VO}_{2}$ pico + leguminosas, ejercicio a $65 \% \mathrm{VO}_{2}$ pico + leguminosas, sólo ejercicio a $45 \% \mathrm{VO}_{2}$ pico y sólo inclusión de leguminosas en la dieta. En cada grupo se incluyeron de 20 a 23 mujeres jóvenes sedentarias evaluadas mediante el International Physical Activity Questionnaire (IPAQ), y la intervención se llevó a cabo durante 4 semanas. La prescripción del ejercicio se hizo previa determinación del $\mathrm{VO}_{2}$ pico por ergo espirometría, y su realización se monitoreó con sensores de frecuencia cardíaca. El efecto

* Research funded by the Office of Research Promotion of the Academic Vice Rectory at Pontificia Universidad Javeriana, Bogotá, DC, Colombia.

1. Analysis of Food Security Research Group, Nutrition and Biochemical Department, Science Faculty, Pontificia Universidad Javeriana, Bogotá, DC, Colombia. e-mail: lfajardo@javeriana.edu.coｄoraginneth@gmail.com nvargas@javeriana.edu.co@mguerra@javeriana.edu.co

2 Director Biomechanics Laboratory, Engineer Faculty, Pontifica Universidad Javeriana, Bogotá, DC, Colombia. e-mail:1quin@javeriana.edu.co

3. Sport Medicine Specialist. e-mail: johnson.nino@javeriana.edu.co

Received for publication Marach 23, 2009 Accepted for publication April 19, 2010 
de la intervención se evaluó mediante los cambios en los niveles séricos de colesterol total (CT), colesterol LDL (cLDL), colesterol HDL (cHDL) y triacilgliceroles (TAG), tomados a las semanas cero, dos y cuatro.

Resultados: En el grupo «ejercicio a $65 \%$ del $\mathrm{VO}_{2}$ pico, más inclusión de leguminosas en la dieta» se obtuvieron los siguientes resultados significantes: una reducción promedio del colesterol total de $19.8 \mathrm{mg} / \mathrm{dl}(\mathrm{p}=0.0015)$, del colesterol LDL de $21.8 \mathrm{mg} / \mathrm{dl}$ ( $\mathrm{p}=0.0001)$, un aumento de colesterol HDL de $6.2 \mathrm{mg} / \mathrm{dl}(\mathrm{p}=0.0001)$ y una disminución de los triacilgliceroles de $20.7 \mathrm{mg} / \mathrm{dl}$ ( $\mathrm{p}=0.0001$ ). En el grupo de sólo ejercicio a $65 \%$ del $\mathrm{VO}_{2}$ pico se obtuvo un aumento del HDL. No hubo modificaciones al perfil lipídico en el grupo correspondiente a sólo inclusión de leguminosas en la alimentación.

Conclusiones: Los resultados sugieren que en mujeres jóvenes sedentarias que viven a 2,640 metros sobre el nivel del mar, la combinación de ejercicio de intensidad alta e inclusión de leguminosas (fríjol, lenteja o garbanzos) producen un mayor cambio benéfico en el perfil lipídico que una intervención con sólo ejercicio de intensidad alta o sólo inclusión de leguminosas en la alimentación. Los cambios benéficos significantes se obtuvieron luego de 4 semanas de intervención en el colesterol total, colesterol LDL, colesterol HDL y triacilgliceroles, lo que pone de presente la bondad de esta intervención, así como la utilidad del perfil lipídico como indicador temprano de cambios en los estilos de vida. Las intervenciones estudiadas, compatibles con alimentación y estilo de vida saludables, producen efectos diferentes en los niveles del perfil lipídico estudiados, y al poner de presente las debilidades de un diseño no aleatorizado, se puede recomendar que se insista en las intervenciones de salud pública que contemplen cambios en la dieta y cambios en la actividad física.

\section{Palabras clave: Alimentación saludable; Dieta; Perfil lipídico; Intensidad de ejercicio; Consumo de leguminosas.}

The World Health Organization (WHO) holds that a healthy diet and adequate physical activity are main factors in the promotion and maintenance of good health throughout the whole life cycle ${ }^{1}$. In Colombia, this recommendation is adopted by the National Plan for Public Health, which among its central issues includes improving the health status of the population and avoiding the progress and occurrence of adverse outcomes in the population on the risk of becoming $\mathrm{ill}^{2}$. The National Policy on Food Safety, specifically announces as one of its objectives «To promote healthy habits and life styles that permit improving the population's state of health and nutrition, and preventing the appearance of dietassociated illnesses» ${ }^{3}$.

In spite of the urgency expressed by the organizations mentioned, the operational definitions that may lead to the quick adoption of a healthy diet and adequate physical exercise practiced regularly are scarce. In this sense, WHO recommendations can be classified as restrictive recommendations (those that begin by «limiting») like limiting the energy intake from fats, limiting sugar and salt intake, etc., and promotional recommendations like increasing intake of fruits and vegetables, legumes, grains, and dry fruits.

With respect to physical activity, it is recommended that people keep physically active during their whole lives with at least 30 minutes of moderate intensity regular activity on an almost daily basis ${ }^{4}$.

There are many combinations of dietary intervention, different from the restrictive ones, related to achieving healthy eating. The recommendation of increasing the intake of fruits and vegetables, legumes, grains, and dry fruit is very general and does not specify value of the increase, $5 \%, 10 \%$, or $20 \%$, or if all have to be increased at the same time, or if it suffices with only increasing any or some of these. The publication of the «Steps to Better Health» food pyramid in the United States offers indications on the minimum amounts, according to eating habits of North Americans, for whom legumes are recommended in portions much lower than those usually consumed in Colombia ${ }^{5}$. Likewise, aerobic exercise is one of the therapeutic focuses related to life style and it is recommended to improve lipid and lipoprotein levels in all individuals, including those with cardiovascular problems. However, except for the general recommendation of almost daily engaging in moderate intensity exercise lasting at least 30 minutes, there is no specification of what is the desirable level of intervention in public health.

There is information available on the positive effect of the intake of legumes and dry whole grains on the lipid profile and glycemia levels, both in healthy and ill individuals ${ }^{6-10}$. There is also evidence of the beneficial effect of exercise, although random tests have yielded conflictive results, perhaps due to differences at the base line, characteristics of the exercise program, and duration of the intervention ${ }^{11,12}$.

With the purpose of contributing to the knowledge of some practical aspects to engaging in healthy eating and 
life style, we present the results of the effects on the lipid profile by including legumes (beans, lentils, and chick peas) in the diet of healthy but sedentary women at the beginning of the study, accompanied by exercise at two intensity levels: moderate and high. The participants live at 2640 meters above sea level (masl).

\section{MATERIALS AND METHODS}

Design. The research was conducted in Bogotá (2640 masl) and it was a Clinical Intervention Study with four phases each lasting four weeks, which meant the participation of 4 groups of 20 young sedentary women, who were subjected to exercise and food intake intervention, which consisted in including legumes for lunch three times per week. Assignment of participants to a particular group was not done randomly. The groups were the following: Group 1: Food intake and exercise intervention with a training workload equivalent to $45 \%$ of the peak oxygen consumption - maximum oxygen update $-\left(\mathrm{VO}_{2}\right.$ peak $)$ by the subject. Group 2: Food intake and exercise intervention with a training workload equivalent to $65 \%$ of $\left(\mathrm{VO}_{2}\right.$ peak) by the subject. Group 3: No food intake intervention, exercise intervention with a training workload equivalent to $65 \%$ of $\left(\mathrm{VO}_{2}\right.$ peak) by the subject. Group 4: Food intervention for 4 weeks, but without exercise intervention.

Subjects. Through announcements on the Universidad Javeriana web page, female students were summoned to express their interest in participating in a clinical research related with food intake and physical activity. Four calls were made during four different weeks, corresponding to each phase of the research. Between 30 and 40 students expressed interest during each invitation. Assignment of the subjects to each intervention group was not random and it was done sequentially.

The following inclusion criteria were considered: a) the subjects identified themselves as sedentary (without regular physical activity during the three months prior to the project, especially without physical activity lasting half an hour or more), b) during a physical activity evaluation prior to the intervention, the subjects were catalogued as sedentary by using the abbreviated version of the "International Physical Activity Questionnaire» (International Consensus Group for the Development of an International Physical Activity Questionnaire, WHO 1996), c) age 18 to 29 years, d)
Body mass index $<28$, e) fitness to practice physical exercise and consume legumes evaluated through physical exam and history carried out by a physician. The exclusion criteria considered: Abnormal base line lipid profile, missing two or more exercise sessions or legume intakes.

Of the students expressing interest, we selected the first 25 students who completed an interview with a nutritionist, a medical exam, and theinternational physical activity questionnaire (IPAQ). Of these, 23 were included in the study and 2 remained on standby.

In total, 89 young women were included ranging from 18 to 30 years of age, university students at Pontifica Universidad Javeriana in Bogotá according to calculation of the sample: $n\left[n=2 S^{2} / D^{2} F(a-b)\right]$ of 23 individuals per group to detect a difference of $2.2 \mathrm{mg} / \mathrm{dl}$ HDL, after 4 weeks of intervention, assuming a standard deviation of $2.7 \mathrm{mg} / \mathrm{dl}$, and a $0.05 \%$ significance level one tail and power of $80 \%$.

The participants were informed on the nature of the study and accepted to participate, signing an informed consent according to guidelines by the Research Committee at Pontificia Universidad Javeriana. All the subjects were in good health and presented no contraindication for exercise and ingestion of prescribed foods according to the medical exam performed on each subject.

Food-Intake Intervention. For food-intake intervention, the subjects were prescribed lunch including legumes as low glycemic level food (beans, lentils, or chick peas), in amounts that would provide $13 \%$ of the daily energy intake. The lunch was calculated to account for $30 \%$ of the daily energy intake. This lunch was offered between 12 noon and 1 pm, 3 days per week during the 4 weeks of the intervention for groups 1,2 , and 4 . For the dietary prescription, we kept in mind the usual values of energy ingestion and other nutrients, along with the feeding characteristics of each individual, obtained through a detailed dietary assessment. The lunch offered included the following foods: red beans, lentils, or chick peas (130-140 g), cooked white rice (70 $\mathrm{g}$ ), fruit $(80 \mathrm{~g})$, raw or cooked vegetable $(75 \mathrm{~g})$ and an unsweetened beverage or natural lemonade $(250 \mathrm{ml})$. The subjects were instructed to always consume the amount of legumes offered and the other foods making up the lunch ad libitum.

During each of the days of intervention (three days 
per week for 4 weeks) each subject recorded the weight of the food portions consumed during the day. To comply with this activity, they were furnished a weighing scale and a measuring cup.

Exercise intervention. The exercise prescription for the intervention was done by first determining the $\mathrm{VO}_{2}$ peak for each individual through ergospirometry with a Metapeak $\mathrm{III}^{\circledR}$ ergospirometer and an exercise protocol with increasing load on an Ergoline ${ }^{\circledR}$ cycloergometer, according to parameters established by Astrand and Wasserman ${ }^{13}$. Rest for 3 minutes on the bike to stabilize the parameters measured before starting the ergospirometry; Warm up by pedaling for 3 minutes at minimum power (15 watts); during this stage, each subject had to pedal at a constant rhythm between 60 and 70 revolutions per minute (rpm); the test included power increases of 15 watts every 3 minutes until reaching a respiratory coefficient of 1.15 or more, or $\bullet$ $\mathrm{VO}_{2}$ Plateau, in spite of the increased exercise load or - not being able to keep pedaling at the same rate of frequency.

Group 1 was prescribed 30 minutes of exercise, 3 days per week with cardiac frequency equivalent to $45 \%$ of $\mathrm{VO}_{2}$ peak. Groups 2 and 3 were prescribed 30 minutes of exercise 3 days per week with cardiac frequency equivalent to $65 \%$ of $\mathrm{VO}_{2}$ peak. The participants in the study were instructed to do the exercise on the athletic field at Universidad Javeriana or at the same university's Sports Center. In both situations, the participants were accompanied by a trained physical therapist. The subjects were free to do the exercise at their convenience between 9 am and $3 \mathrm{pm}$. During each programmed exercise session, each participant wore a cardiac frequency monitor (Timex Iron Man ${ }^{\circledR}$ or Polar S810®) capable of storing the time at which the subject reached and maintained the target cardiac frequency; this time was denominated time in zone. The study also stored the average cardiac frequency obtained over the time each exercise session was developed. Ideally, the time in zone and the average cardiac frequency during the activity should coincide with the time prescribed and the target cardiac frequency prescribed. During the programmed exercise sessions, the subjects were also asked for their perception of effort by using the Borg scale.

Determination of lipoproteins. Blood samples were taken from the antecubital vein during the early morning hours after 12-hour fasting. Total cholesterol and triglyceride concentrations were analyzed via colorimetric enzyme assays (Serapak-Bayer). HDL cholesterol (HDL) was determine don the supernatant by centrifugation, post precipitation (chylomicrons, VLDL cholesterol (VLDL) and LDL cholesterol) with phosphotungstic acid and magnesium ions (SerapakBayer). LDL cholesterol and VLDL cholesterol levels were calculated by using the Friedwald formula when the samples did not have triglycerides greater than 400 $\mathrm{mg} / \mathrm{dl}^{14}$. The assessments were made on an RA 50 (Bayer) instrument at the Clinical Biochemistry Specialization Laboratory at Pontificia Universidad Javeriana in Bogotá DC, and to control instrument efficiency, we used known-concentration calibrators (SERA CHEK from BAYER Labs SA).

Statistical analysis. The statistical analysis was aimed at determining the differences in serum biochemical parameter measurements prior to intervention and after two and four weeks of intervention for the 4 groups intervened. One-way and contrast variance analysis tests were run via the Bonferroni method to study the differences in biochemical parameter changes among the four intervention groups, and Student $t$ tests were run and confidence interval at $95 \%$ (CI 95\%) to determine the significance of the differences in the biochemical parameters measured at the base line and after four weeks of intervention. The Stata IC version 10 statistical package was used.

\section{RESULTS}

The study included 81 women (Table 1), ranging in age between 18 and 29 years; with an average age of 20.89 years (CI 95\% 20.45-21.33) average weight of $54.52 \mathrm{~kg}$. (CI 95\% 53.19-55.84), average height of 1.58 $\mathrm{m}$ (CI 95\% 1.56-1.59) and average Body Mass Index (BMI) of 21.78 (95\% CI 21.33-22.23).

The subjects programmed for the dietary intervention, groups 1,2 , and 4, during the days programmed had an intake of $14 \%, 16 \%$, and $16 \%$ of the total daily energy as legumes, respectively, and energy intake was reduced by $15 \%$ in group 1 and by $22.6 \%$ in group 2 (in group 4 this parameter was not evaluated). Note that the food intake was not stimulated by the researchers, but was rather spontaneously given (Table 2).

Exercise intervention was carried out with 61 
Table 1

Characteristics of the women included in the study per intervention group

\begin{tabular}{|c|c|c|c|c|}
\hline \multirow[t]{2}{*}{ Group } & \multirow[t]{2}{*}{$\mathrm{N}^{\circ}$ subjects } & \multirow{2}{*}{$\begin{array}{c}\text { Average } \\
\text { Age (years) }\end{array}$} & \multicolumn{2}{|c|}{ Cl 95\% ${ }^{1}$} \\
\hline & & & Inf & Sup \\
\hline Exercise at $45 \% \mathrm{VO}_{2}$ peak + legumes & 23 & 20.3 & 19.7 & 20.9 \\
\hline Exercise at $65 \% \mathrm{VO}_{2}$ peak + legumes & 23 & 20.0 & 19.3 & 20.7 \\
\hline Only exercise at $65 \% \mathrm{VO}_{2}$ peak & 18 & 22.1 & 21.3 & 23.0 \\
\hline \multirow[t]{2}{*}{ Only intake of legumes } & 20 & 21.5 & 20.4 & 22.6 \\
\hline & & \multicolumn{3}{|c|}{ Initial weight (kg) } \\
\hline Exercise at $45 \% \mathrm{VO}_{2}$ peak + legumes & 23 & 53.8 & 51.4 & 56.1 \\
\hline Exercise at $65 \% \mathrm{VO}_{2}$ peak + legumes & 23 & 55.7 & 53.5 & 57.9 \\
\hline Only exercise at $65 \% \mathrm{VO}_{2}$ peak & 18 & 53.3 & 50.6 & 56.1 \\
\hline \multirow[t]{2}{*}{ Only intake of legumes } & 20 & 55.0 & 51.7 & 58.4 \\
\hline & & \multicolumn{3}{|l|}{ Height (m) } \\
\hline Exercise at $45 \% \mathrm{VO}_{2}$ peak + legumes & 23 & 1.6 & 1.6 & 1.6 \\
\hline Exercise at $65 \% \mathrm{VO}_{2}$ peak + legumes & 23 & 1.6 & 1.6 & 1.6 \\
\hline Only exercise at $65 \% \mathrm{VO}_{2}$ peak & 18 & 1.6 & 1.6 & 1.6 \\
\hline \multirow[t]{2}{*}{ Only intake of legumes } & 20 & 1.6 & 1.5 & 1.6 \\
\hline & & \multicolumn{3}{|l|}{$\mathrm{BMI}^{32}\left(\mathrm{~kg} / \mathrm{m}^{2}\right)$} \\
\hline Exercise at $45 \% \mathrm{VO}_{2}$ peak + legumes & 23 & 21.5 & 20.5 & 22.4 \\
\hline Exercise at $65 \% \mathrm{VO}_{2}$ peak + legumes & 23 & 22.1 & 21.4 & 22.8 \\
\hline Only exercise at $65 \% \mathrm{VO}_{2}$ peak & 18 & 21.3 & 20.4 & 22.2 \\
\hline Only intake of legumes & 20 & 22.3 & 21.2 & 23.3 \\
\hline
\end{tabular}

1. $\mathrm{Cl} 95 \%=$ Confidence interval at $95 \% 2 . \mathrm{BMI}=$ Body Mass Index

participants in the following manner: Group 1 had 12 exercise sessions (sessions 3 days per week for 4 weeks), prescribed at an intensity of $45 \%$ of $\mathrm{VO}_{2}$ peak, and done at an average intensity of $47 \%$ of $\mathrm{VO}_{2}$ peak. Group 2 had 12 programmed sessions with intensity at $65 \%$ and effectively done at an average intensity of $63.3 \%$ of $\mathrm{VO}_{2}$ peak, and group 3 also had 12 programmed exercise sessions with an intensity at $65 \%$ of $\mathrm{VO}_{2}$ peak that were done at an average intensity of $60.2 \%$ of $\mathrm{VO}_{2}$ peak (Table 3).

Lipid profile measurements were done prior to starting the intervention, at two weeks of intervention and after four weeks of intervention. Base line measurements were taken from 88 subjects, at two weeks in 87 individuals and after 4 weeks in 82 individuals.

The result of the interventions on the lipid profile was evaluated through TC, LDL, HDL, and TAG serum measurements. For the 4 groups intervened, we calculated, in the four components of the lipid profile, the average of differences $(\delta)$ among the base line values and after four weeks of intervention (delta $(\delta)=$ base line value - value after four weeks of intervention).

In Table 4 we show the ä changes occurring in the levels of the lipid profile parameters after 4 weeks of intervention (note that the positive values indicate diminishing of the serum level profile and the negative values indicate increased serum level). The statistical significance of the differences $(\delta)$ among the intervention groups was evaluated through one-way variance analysis of the $\delta$ for the 4 groups and following contrasts via the Bonferroni test (Table 5). We also studied the difference of the serum values at the base line and after four weeks of intervention and were compared through a Student t test. These data are presented in Table 6.

Total cholesterol. It was observed that in the intervention group of $«$ Exercise at $65 \% \mathrm{VO}_{2}$ peak + 
Table 2

Energy intake and fat and cholesterol supply before and during the study per intervention group

\begin{tabular}{|c|c|c|c|}
\hline & $\begin{array}{l}\text { Food intake before } \\
\text { the Intervention }\end{array}$ & $\begin{array}{l}\text { Food intake during } \\
\text { the Intervention }\end{array}$ & $\%$ change \\
\hline \multicolumn{4}{|c|}{ Group 1: Exercise at $45 \% \mathrm{VO}_{2}$ peak + legumes } \\
\hline Daily energy intake & 1600.27 & 1346.07 & 15.9 \\
\hline$\%$ of energy from fat & 30.3 & 25.9 & 14.7 \\
\hline $\mathrm{mg}$ of cholesterol/day & 365.69 & 206.76 & 43.5 \\
\hline$\%$ of energy from legumes & 1.1 & 14.6 & \\
\hline \multicolumn{4}{|c|}{ Group 2: Exercise at $65 \% \mathrm{VO}_{2}$ peak + legumes } \\
\hline Daily energy intake & 1507.44 & 1165.93 & 22.7 \\
\hline$\%$ of energy from fat & 30.8 & 23.6 & 23.2 \\
\hline $\mathrm{mg}$ of cholesterol/day & 271.08 & 152.30 & 43.8 \\
\hline$\%$ of energy from legumes & 1.7 & 16.1 & \\
\hline \multicolumn{4}{|c|}{ Group 3: Only exercise at $65 \% \mathrm{VO}_{2}$ peak } \\
\hline Energy intake & Ad libitum & Ad libitum & - \\
\hline \multicolumn{4}{|c|}{ Group 4: Only included legumes } \\
\hline Daily energy intake & - & 1250 & - \\
\hline$\%$ of energy from fat & - & 24.5 & - \\
\hline $\mathrm{mg}$ of cholesterol/day & - & 165 & - \\
\hline$\%$ of energy from legumes & - & 16.2 & - \\
\hline
\end{tabular}

Table 3

Intensity of exercise and time of execution effectively carried out during the intervention of the exercise per study group

\begin{tabular}{|c|c|c|c|c|c|c|}
\hline \multirow[t]{2}{*}{ Group } & \multirow[t]{2}{*}{$\begin{array}{c}\mathrm{N} \\
\text { subjects }\end{array}$} & \multicolumn{2}{|c|}{$\begin{array}{l}\text { Intensity of the exercise done as a } \\
\text { percentage of } \mathrm{VO}_{2} \text { peak }^{*}(\mathrm{ml} / \mathrm{kg} / \mathrm{min})\end{array}$} & \multicolumn{3}{|c|}{$\begin{array}{l}\text { Time of exercise in prescribed zone - } \\
\text { minutes total exercise time }\end{array}$} \\
\hline & & Group average & Standard deviation & Group average & $\begin{array}{l}\text { Standard } \\
\text { deviation }\end{array}$ & $\min$ \\
\hline 1 & 23 & 47.2 & 6.3 & 21.3 & 3.1 & 30 \\
\hline 2 & 23 & 63.3 & 5.6 & 20.5 & 4.2 & 30 \\
\hline 3 & 15 & 60.2 & 6.2 & 20.3 & 5.2 & 30 \\
\hline 4 & 20 & - & - & - & - & - \\
\hline
\end{tabular}

* Calculated from the average cardiac frequency during exercise and calibrated for each individual in ergospirometry test 
Table 4

Average of differences in lipid profile between base line and after four weeks per intervention group and component

\begin{tabular}{lcccc}
\hline \multicolumn{1}{c}{ Group } & $\boldsymbol{\delta}^{\mathbf{1}} \mathbf{T C}^{2}$ & $\boldsymbol{\delta}$ LDL $^{3}$ & $\boldsymbol{\delta}$ HDL $^{4}$ & $\boldsymbol{\delta}$ TAG $^{5}$ \\
\hline Exercise at $45 \% \mathrm{VO}_{2}$ peak + legumes & 7.3 & 6.8 & -0.9 & 6.8 \\
Exercise at $65 \% \mathrm{VO}_{2}$ peak + legumes & 19.8 & 21.8 & -6.2 & 20.7 \\
Only exercise at $65 \% \mathrm{VO}_{2}$ peak & -8.4 & -7.6 & -5.1 & 19.6 \\
Only included legumes & -8.7 & -4.3 & 2.0 & -8.4 \\
\hline
\end{tabular}

1. $\delta=$ Change in one of the fractions of the lipid profile. $2 . T C=$ Total cholesterol. $3 . \mathrm{LDL}=$ Cholesterol associated to low-density lipoproteins.

4. $\mathrm{HDL}=$ Cholesterol associated to high-density lipoproteins. 5. $\mathrm{TAG}=$ Triacylglycerols

Table 5

Average of the differences of the lipid profile parameters before and after the intervention ( $\delta$ ) per contrast groups and Bonferroni statistical significance test after 1-way ANOVA for 4 groups

\begin{tabular}{|c|c|c|c|}
\hline \multicolumn{3}{|c|}{ Average of differences $(\delta)$ per contrast groups } & \multirow{2}{*}{$\begin{array}{c}\text { Bonferroni } \\
\text { test }\end{array}$} \\
\hline & Exercise at $65 \% \mathrm{VO}_{2}$ peak + legumes & Only exercise at $65 \% \mathrm{VO}_{2}$ peak & \\
\hline$\delta$ total cholest & 19.8 & -8.4 & $p=0.002$ \\
\hline$\delta$ Ldl & 21.8 & -7.6 & Ns \\
\hline$\delta \mathrm{Hdl}$ & -6.2 & -5.1 & Ns \\
\hline \multirow[t]{2}{*}{$\delta$ triacylglycerols } & 20.7 & 19.6 & Ns \\
\hline & Exercise at $65 \% \mathrm{VO}_{2}$ peak + legumes & Only included legumes & \\
\hline$\delta$ total cholest & 19.8 & -8.7 & $\mathrm{p}=0.002$ \\
\hline$\delta$ Ldl & 21.8 & -4.3 & $p=0.001$ \\
\hline$\delta \mathrm{Hdl}$ & -6.2 & 2.0 & $p=0.001$ \\
\hline \multirow[t]{2}{*}{$\delta$ triacylglycerols } & 20.7 & -8.4 & $p=0.002$ \\
\hline & Exercise at $65 \% \mathrm{VO}_{2}$ peak + legumes & Only included legumes & \\
\hline$\delta$ total cholest & -8.4 & -8.7 & Ns \\
\hline$\delta$ Ldl & -7.6 & -4.3 & Ns \\
\hline$\delta \mathrm{Hdl}$ & -5.1 & 2.0 & $p=0.003$ \\
\hline \multirow[t]{2}{*}{$\delta$ triacylglycerols } & 19.6 & -8.4 & $p=0.009$ \\
\hline & Exercise at $65 \% \mathrm{VO}_{2}$ peak + legumes & Exercise at $45 \% \mathrm{VO}_{2}$ peak+ legumes & \\
\hline$\delta$ total cholest & 19.8 & 7.3 & Ns \\
\hline$\delta$ Ldl & 21.8 & 6.8 & Ns \\
\hline$\delta \mathrm{Hdl}$ & -6.2 & -0.9 & $p=0.021$ \\
\hline$\delta$ triacylglycerols & 20.7 & 6.8 & Ns \\
\hline
\end{tabular}

$\delta=$ Change in each of the lipid profile fractions in base line and after intervention 
Table 6

Serum level average of lipid profile components at the base line and after four weeks of intervention per intervention group

\begin{tabular}{|c|c|c|c|c|c|}
\hline & \multicolumn{2}{|c|}{ Base line } & \multicolumn{2}{|c|}{ After Intervention } & \multirow[b]{2}{*}{ t test } \\
\hline & Average & $95 \% \mathrm{Cl}^{2}$ & Average & $95 \% \mathrm{Cl}^{2}$ & \\
\hline \multicolumn{6}{|l|}{ Total Cholesterol } \\
\hline Exercise at $45 \% \mathrm{VO}_{2}$ peak+ legumes & 169.7 & $158.4-181.0$ & 162.4 & $150.6-174.3$ & \\
\hline Exercise at $65 \% \mathrm{VO}_{2}$ peak + legumes & 172.6 & $161.7-183.5$ & 153.5 & $145.9-161.0$ & $p=0.0048$ \\
\hline Only Exercise at $65 \% \mathrm{VO}_{2}$ peak & 144.3 & $130.7-157.9$ & 153.3 & $140.0-166.6$ & \\
\hline Only included legumes & 161.1 & $149.1-173.2$ & 169.8 & $155.2-184.4$ & \\
\hline \multicolumn{6}{|l|}{ LDL Cholesterol } \\
\hline Exercise at $45 \% \mathrm{VO}_{2}$ peak+ legumes & 99.0 & $88.8-109.1$ & 92.1 & $83.6-100.6$ & \\
\hline Exercise at $65 \% \mathrm{VO}_{2}$ peak + legumes & 101.7 & $93.2-110.2$ & 81.1 & $75.7-86.5$ & $p=0.0001$ \\
\hline Only Exercise at $65 \% \mathrm{VO}_{2}$ peak & 71.4 & $58.4-84.3$ & 78.8 & $67.4-90.1$ & \\
\hline Only included legumes & 90.6 & $80.6-100.7$ & 94.9 & $82.5-107.3$ & \\
\hline \multicolumn{6}{|l|}{ HDL Cholesterol } \\
\hline Exercise at $45 \% \mathrm{VO}_{2}$ peak+ legumes & 52.1 & $46.5-57.7$ & 53.0 & $47.2-58.7$ & \\
\hline Exercise at $65 \% \mathrm{VO}_{2}$ peak + legumes & 51.2 & $48.9-53.5$ & 57.6 & $56.0-59.3$ & $\mathrm{p}=0.0001$ \\
\hline Only Exercise at $65 \% \mathrm{VO}_{2}$ peak & 49.8 & $45.8-53.7$ & 55.9 & $51.8-59.9$ & $\mathrm{p}=0.0219$ \\
\hline Only included legumes & 56.1 & $52.7-59.5$ & 54.1 & $50.8-57.5$ & \\
\hline \multicolumn{6}{|l|}{ Triacylglycerols } \\
\hline Exercise at $45 \% \mathrm{VO}_{2}$ peak+ legumes & 91.5 & $71.5-111.4$ & 84.7 & $70.1-99.3$ & \\
\hline Exercise at $65 \% \mathrm{VO}_{2}$ peak + legumes & 86.2 & $77.8-94.7$ & 64.9 & $58.8-71.1$ & $p=0.0001$ \\
\hline Only Exercise at $65 \% \mathrm{VO}_{2}$ peak & 103.3 & $81.5-125.0$ & 81.6 & $65.9-97.3$ & $p=0.0642$ \\
\hline Only included legumes & 84.6 & $69.2-100.1$ & 93.0 & $72.2-113.8$ & \\
\hline
\end{tabular}

legumes» the maximum reduction was obtained (greater size $\delta$ ) for the TC value, and that this $\delta$ was significantly different to that observed in the groups «Only exercise at $65 \% \mathrm{VO}_{2}$ peak» (Bonferroni $\mathrm{p}=0.002$ ) and «Only included legumes» $($ Bonferroni $\mathrm{p}=0.001)$, (Tables 4 and $5)$.

In the group of «Exercise at $65 \% \mathrm{VO}_{2}$ peak + legumes» a decrease of serum TC was observed after four weeks of intervention, which was statistically significant for the $t$ test $(\mathrm{p}=0.0048)$ (Table 6). To evaluate the possibility of a dosage response effect an ANOVA was run of the TC including the terms group and week, revealing a significant effect for the term Group $(\mathrm{F}=5.04, \mathrm{p}=0.0021)$, but not for the term Week
$(\mathrm{F}=0.29, \mathrm{p}=0.7496)$, thus discarding a dosage response effect of the time of intervention.

Upon analyzing group averages of the TC presented in Table 6, it can be observed that the base line values for the four intervention groups are within the normal limits; however, the base line of the intervention group of «Only exercise at $65 \% \mathrm{VO}_{2}$ peak», revealed significantly lower figures than groups of «Exercise at $45 \% \mathrm{VO}_{2}$ peak + legumes» and «Exercise at $65 \% \mathrm{VO}_{2}$ peak + legumes» (one-way ANOVA F 4.74, $\mathrm{p}=0.0042$; Bonferroni contrast $\mathrm{p}=0.016$ and 0.005 ). We have no definite explanation for these differences and they could be attributed to bias in the selection of the participants in this group, which should be kept in mind in the 
discussion and conclusions because reductions are more difficult when starting with low TC values.

LDL cholesterol. The greatest value of $\delta$ LDL was observed for the group «Exercise at $65 \% \mathrm{VO}_{2}$ peak + legumes», followed by the value obtained by the group «Exercise at $45 \% \mathrm{VO}_{2}$ peak+ legumes» (Tables 4 and $5)$. These data reveal that the maximum reduction in LDL (greatest value of $\delta$ LDL) was obtained in the group «Exercise at $65 \% \mathrm{VO}_{2}$ peak + legumes», this reduction merely being significantly greater than that observed in the group «Only inclusion of legumes».

Likewise, the group «Exercise at $65 \%$ VO2 peak + legumes» also showed a significant reduction in average LDL, going from $101.1 \mathrm{mg} / \mathrm{dl}$ to $81.1 \mathrm{mg} / \mathrm{dl}$ ( $\mathrm{p}=0.0001$ ). The possibility of a dosage response effect was analyzed via an ANOVA of the LDL including the terms Group and Week. The ANOVA (LDL-Group-Week) was significant $(\mathrm{F}=5.23, \mathrm{p}=0.0001)$, with the term Group also being significant $(\mathrm{p}<0.0001)$, but not so for the term week.

HDL cholesterol. The most negative values for $\delta$ HDL in Table 4 (greater increases of HDL) were seen in the intervention groups «Exercise at $65 \% \mathrm{VO}_{2}$ peak + legumes» and «Only exercise at $65 \% \mathrm{VO}_{2}$ peak». In the group «Only inclusion of legumes» favorable HDL level changes were not observed. And in the group «Exercise at $45 \% \mathrm{VO}_{2}$ peak+ legumes» HDL increase was lower than in the groups with greater intensity exercise.

The comparison of HDL values at the base line and after 4 weeks of intervention demonstrated a significant increase for the groups «Exercise at $65 \% \mathrm{VO}_{2}$ peak + legumes» $(51.2 \mathrm{mg} / \mathrm{dl}$ to $57.6 \mathrm{mg} / \mathrm{dl})$ and «Only exercise at $65 \% \mathrm{VO}_{2}$ peak» $(49.8 \mathrm{mg} / \mathrm{dl}$ to $55.9 \mathrm{mg} / \mathrm{dl})$ (Table 6). The ANOVA (HDL-Group-Week) was not significant $(\mathrm{F}=1.12, \mathrm{p}=0.3511)$.

Triacylglycerols. As in the case of the other lipid profile components, the differences in TAG serum values on the base line and after intervention $(\delta$ TAG) in the intervention groups are shown in Tables 4 and 5.

The three intervention groups including exercise, revealed the greatest reduction of serum TAG levels $(\delta$ TAG), greatest in the groups of exercise with intensity greater than $\left(65 \% \mathrm{VO}_{2}\right.$ peak). In the group of «Only inclusion of legumes» we observed a $\delta \mathrm{TAG}=-8.4$ (negative value), which indicates increased TAG levels post intervention.
The TAG averages for the group «Exercise at $65 \%$ $\mathrm{VO}_{2}$ peak + legumes» (Table 6) show significant diminishing of serum level going from $86.2 \mathrm{mg} / \mathrm{dl}$ to 64.9 $\mathrm{mg} / \mathrm{dl}, \mathrm{p}=0.0001$. The ANOVA analysis (TAG - Group - Week) showed the existence of an effect on TAG levels attributable to the Intervention Group (ANOVA $\mathrm{F}=2.60, \mathrm{p}=0.05$ ), but not an effect attributable to time of intervention in weeks.

\section{DISCUSSION}

The study considered young, sedentary women with life styles concordant with their condition as university students, living in Bogotá DC, at an altitude of 2,640 masl. The change in lipid profile was evaluated as an indication of the beneficial effect of four weeks of intervention with actions that could become part of a healthy life style.

The four intervention groups in this work were thus: Exercise at $45 \%$ of $\mathrm{VO}_{2}$ peak ( 4 METs - moderateintensity exercise) plus inclusion of legumes in diet, Exercise at $65 \%$ of $\mathrm{VO}_{2}$ peak ( $6 \mathrm{METs}$ high-intensity exercise) plus inclusion of legumes in diet, Exercise at $65 \%$ of $\mathrm{VO}_{2}$ peak ( $\sim 6$ METs high-intensity exercise) without dietary intervention (time of exercise: 30 minutes three days per week), and finally, diet intake intervention including legumes without changes physical activity levels; may be seen as differentimplementation stadiums to accomplishing healthy feeding and life styles.

The results shown in Tables 4 and 5 refer to the differences in the magnitude of change obtained through the interventions. In the group «Exercise at $65 \%$ of $\mathrm{VO}_{2}$ peak + inclusion of legumes in diet» significant statistical and physiological results were obtained. We obtained an average reduction in TC of $19.8 \mathrm{mg} / \mathrm{dl}$, in LDL of 21.8 $\mathrm{mg} / \mathrm{dl}$, an increase in HDL of $6.2 \mathrm{mg} / \mathrm{dl}$, and reduction in TAG of $20.7 \mathrm{mg} / \mathrm{dl}$. In the group of exercise at $45 \%$ of $\mathrm{VO}_{2}$ peak (moderate intensity) plus inclusion of legumes changes obtained were in the expected direction, but at a lower magnitude and not statistically significant. The values were: a reduction of $7.3 \mathrm{mg} / \mathrm{dl}$ in $\mathrm{TC}$, a reduction of $6.8 \mathrm{mg} / \mathrm{dl}$ in LDL, and an increase of $0.9 \mathrm{mg} / \mathrm{dl}$ in HDL.

Strategies by the WHO to prevent chronic illnesses ${ }^{1}$ contemplate efforts to have people consume healthy diets and perform moderate physical activity; however, other authors ${ }^{15}$ alert on the difficulties of carrying out 
these interventions. Our results indicate that the combination legume intake (healthy diet) and highintensity exercise is better than any of the other interventions; furthermore, there is a relationship between exercise intensity and the resulting changes in lipid profile.

The current study was conducted at an altitude of 2,640 masl, and the effect of altitude on the physiology of exercise ${ }^{16}$ has been well established. Although with the information available, we cannot confirm or deny the influence of this parameter on the results, we do want to wish to direct attention on this fact given the important number of people living in the Andean high plains. Several studies have shown the relationship between exercise intensity and the effects on lipid profile ${ }^{11,17}$; however, few studies report altitude over the sea level where the exercise is done. It is possible that at the altitude in Bogotá, longer-lasting interventions may be warranted (months instead of weeks). Other studies examining the effect of exercise on TC or on LDL report diminishing of 4 and $5 \%$ with respect to the initial value and indicate that reductions greater than $2 \%$ already have positive effects with respect to reduction of cardiovascular risk ${ }^{11}$.

The group with moderate-intensity exercise and diet intervention showed a tendency for diminished TC, LDL, and TAG; rather, the group with only exercise at $65 \%$ of $\mathrm{VO}_{2}$ peak did not reveal significant reduction of TC or LDL, instead the tendency during the four weeks of intervention was to increase-although not significantly. According to the results of this study, it would seem that to achieve changes in TC, LDL, and TAG parameters, some combination form of legume intake and exercise is needed.

In the group of only dietary intervention, we did not observe the changes associated to the consumption of legumes as reported by other authors ${ }^{6-10}$. An explanation of this result may be the type of legumes used, given that in our case we used canned beans, lentils, and chick peas and in several of the articles cited only beans are consumed; however, the WHO recommends legumes in general. Similarly, it must be kept in mind that the current study was of short duration and the consumption of whole grains and legumes associated to fruits and vegetables for longer periods may be beneficial, as noted with the Mediterranean $\operatorname{diet}^{18}$.

With respect to increased HDL (Table 6) with the type of intervention, significant increases were obtained in the three intervention groups that included exercise; with the greatest increase registered in the groups with exercise intensity at $65 \%$ of $\mathrm{VO}_{2}$ peak. These results agree with the literature, both in the level of increase as in the association between magnitude of change and exercise intensity ${ }^{11}$.

As reported by other studies, TAG levels diminish with exercise and in our study we obtained a reduction of 20.7 and $19.6 \mathrm{mg} / \mathrm{dl}$ in the groups with exercise intensity at $65 \%$ of $\mathrm{VO}_{2}$ peak, without the existence of significant differences attributable to the inclusion of legumes in the dietary intake (Table 6).

Bearing in mind the limitations of a non-random study with only four weeks of observation, the results suggest that greater benefit is obtained with a combination of high-intensity exercise ( $\sim 6$ METS) carried out for 30 minutes three times per week and the inclusion of legumes (beans, lentils, chick peas) in amounts representing $15 \%$ of the daily energy intake, judging such benefit as desirable changes in the lipid profile (Diminishing of TC, LDL, TAG and increase of HDL). Hence, it would be the most desirable combination among those studied. Conversely, by merely including legumes in the dietary intake at the level used and monitoring the lipid profile for 4 weeks, it was not possible toevidence any change in lipid profile, suggesting that the recommendation of «increasing legume consumption» should be carried out for more prolonged periods with intake of greater amounts, i.e., it should be more qualified. The intervention of only high-intensity exercise ( 6 METS) had the effect of increasing HDL, as shown in other studies and diminished TAG $(p=0.06)$ was marginally observed. This study highlights the importance of the dietary intervention, which as with the group of «Exercise at $65 \% \mathrm{VO}_{2}$ peak + legumes» in the current study could be measured by the dietary fiber provided by the legumes and the low-glycemic index of the carbohydrates supplied by these legumes. The intervention with moderate-intensity exercise( 4METS) and legumes revealed changes in the expected direction, but these were not statistically significant. Although the effects of moderate- or low-intensity exercise upon lipid profile is still a motive for discussion ${ }^{19}$, the effects of the altitude where the study was conducted are still an issue of study.

In conclusion, different interventions compatible with 
healthy dietary intake and life style behave differently as far as their effect on the change in the levels of the fractions of the lipid profile studied, and, consequently, the manner of implementing the recommendation to adopt a healthy diet and life style can bear implications on the final outcome.

For the altitude in Bogotá and the age group studied, an intervention with healthy eating and high-intensity exercise for 30 minutes, three days per week produces effects on the lipid profile consistent with diminished risk of cardiovascular disease.

Conflict of interest. None of the authors has conflicts of interest related to this study.

\section{REFERENCES}

1. World Health Organization 2008. 2008-2013 Action plan for the global strategy for the prevention and control of noncommunicable diseases: prevent and control cardiovascular diseases, cancers, chronic respiratory diseases and diabetes. [Date of access 02 March 2009]. Available in: http:// www.who.int/publications/en/

2. Ministerio de la Protección Social. Decreto 3039 de 2007. Plan Nacional de Salud Pública 2007-2010. Bogotá, DC: Ministerio de la Protección Social; 2007.

3. Consejo Nacional de Política Económica Social. Departamento Nacional de Planeación. Documento Conpes Social 113. Política Nacional de Seguridad Alimentaria y Nutricional. Bogotá, DC: Consejo Nacional de Política Económica Social; Bogotá 31 de marzo de 2008.

4. Organización Mundial de la Salud 2004. Estrategia mundial sobre régimen alimentario, actividad física y salud. [Date of access 02 March 2009]. Available in: http://www.who.int/ dietphysicalactivity/strategy/eb11344/strategy_spanish_ web.pdf

5. United States Department of Agriculture. Steps to a healthier you. Inside the Pyramid. What counts as an ounce equivalent in the meat \& beans group? [Date of access 12 March 2009]. Available in: http://www.mypyramid.gov/pyramid/meat_ counts_table.html

6. Jang, Y, Lee JH, Kim OY, Young Park H, Lee SY. Consumption of whole grain and legume powder reduces insulin demand, lipid peroxidation and plasma homocysteine concentrations in patients with coronary artery disease. Arterioscler Thromb
Vasc Biol. 2001; 21: 2065-71.

7. Dumesnil JG, Turgeon J, Tremblay A, Poirier P, Gilbert M, Gagnon L, et al. Effect of a low-glycemic index-low-fat-high protein diet on the atherogenic metabolic risk profile of abdominally obese men. Br J Nutr. 2001; 86: 557-68.

8. Bazzano LA, He J, Ogden LG, Loria C, Vupputuri S, Myers $\mathrm{L}$, et al. Legume consumption and risk of coronary heart disease in US men and women: NHANES I Epidemiologic Follow-up Study. Arch Intern Med. 2001; 161: 2573-78.

9. Kabagambe EK, Baylin A, Ruiz Narvarez E, Siles X, Campos $H$. Decreased consumption of dried mature beans is positively associated with urbanization and nonfatal acute myocardial infarction. J Nutr. 2005; 135: 1770-5.

10. Anderson JW, Major AW. Pulses and lipaemia, short- and long-term effect: potential in the prevention of cardiovascular disease. Br J Nutr. 2002; 88 Suppl 3: 263-71

11. Kelley GA, Kelley KS, Franklin B. Aerobic exercise and lipids and lipoproteins in patients with cardiovascular disease: a meta-analysis of randomized controlled trials. J Cardiopulm Rehabil. 2006; 26: 131-44.

12. Nieman DC, Brock DW, Butterworth D, Utter AC, Nieman CC. Reducing diet and/or exercise training decreases the lipid and lipoprotein risk factors of moderately obese women. J Am Coll Nutr. 2002; 21: 344-50.

13. Astrand PO, Rodahl K. Textbook of work physiology. $2^{\text {nd }}$ ed. New York: McGraw-Hill Book Co; 1977. p. 279.

14. Callas N, Poveda E, Baracaldo C, Hernández P, Castillo C, Guerra N. Polimorfismo genético de la apolipoproteína E en un grupo de escolares del centro-oriente colombiano: comparación con las concentraciones plasmáticas de lípidos y apolipoproteínas. Biomedica. 2007; 27: 526-36.

15. Lean M, Lara J, Hill JO. ABC of obesity. Strategies for preventing obesity. BMJ. 2006; 333: 959-62.

16. NadelE. Exercise physiology and sports science. En: Boron W, Boulpaep E(eds.) Medical Physiology. Philadelphia: Saunders; 2003. p. 1242.

17. Johnson J, Slentz C, Houmard J, Samsa G, Duscha B, Aiken $\mathrm{L}$, et al. Exercise Training amount and intensity effects on metabolic syndrome (from studies of a targeted risk reduction intervention through defined exercise). Am J Cardiol. 2007; 100: $1759-66$.

18. Trichopoulou A, Costacou T, Bamia C, Trichopoulos D. Adherence to a Mediterranean diet and survival in a Greek population. N Engl J Med. 2003; 348: 2599-608.

19. Crouse, S, O'Brien B, Grandjean P, Lowe R, Rohack J, Green $\mathrm{J}$, Tolson T. Training intensity, blood lipids, and apolipoproteins in men with high cholesterol. J Appl Physiol. 1997; 82: 270-7. 